\title{
Annexin Family Protein
}

National Cancer Institute

\section{Source}

National Cancer Institute. Annexin Family Protein. NCI Thesaurus. Code C128917.

A family of proteins that are capable of binding negatively charged phospholipids in a calcium-dependent manner and contain four annexin repeats. This family has been linked with a wide variety of biological processes, including inhibition of phospholipase activity, exocytosis, endocytosis, coagulation, fibrinolysis, the regulation of inflammation and membrane organization. 